\title{
Investigation of Financial Factors Affecting the Income of Share Certificates: An Example of Industrial Companies
}

\author{
Tunahan AVCI iD a \\ a Erciyes University, Department of Aviation Management, Kayseri, Turkey, tnavci@erciyes.edu.tr
}

\begin{tabular}{|c|c|}
\hline ARTICLE INFO & ABSTRACT \\
\hline $\begin{array}{l}\text { Keywords: } \\
\text { Stocks } \\
\text { Industrial Company }\end{array}$ & $\begin{array}{l}\text { Purpose - This study attempted to determine the factors that affect the stock returns of industrial } \\
\text { enterprises operating in the Istanbul Stock Exchnge. In addition, it was investigated whether the } \\
\text { deteriorated economic indicators caused a change in investors' decisions in } 2018 \text {. }\end{array}$ \\
\hline $\begin{array}{l}\text { Return } \\
\text { Financial Ratios }\end{array}$ & $\begin{array}{l}\text { Design/methodology/approach - For this purpose, logistic regression analysis was performed for 2017- } \\
2018 \text { by using the financial ratios of } 147 \text { enterprises in the industrial sector. In the analysis, the stock return }\end{array}$ \\
\hline $\begin{array}{l}\text { Received } 13 \text { October } 2019 \\
\text { Revised } 5 \text { March } 2020 \\
\text { Accepted } 11 \text { March } 2020\end{array}$ & $\begin{array}{l}\text { rate as a dependent variable, and return on equity, market value / book value, price / earnings, receivables } \\
\text { turnover rate, asset turnover rate, inventory turnover rate, debt ratio, gross profit margin, and main } \\
\text { operating profit margin ratios as independent variables were used. }\end{array}$ \\
\hline $\begin{array}{l}\text { Article Classification: } \\
\text { Research Article }\end{array}$ & $\begin{array}{l}\text { Findings - According to the results of the analysis, equity profitability ratio had a significant effect on stock } \\
\text { returns in 2017, while the debt ratio and the main operating profit margin ratio had a significant effect in } \\
2018 \text {. }\end{array}$ \\
\hline & $\begin{array}{l}\text { Discussion - When the results of both years were analyzed, it was seen that the financial factors on stock } \\
\text { returns changed, thus it can be said that there was a change in the investors' decisions. }\end{array}$ \\
\hline
\end{tabular}

\section{INTRODUCTION}

The industrial sector, which plays an important role in the economic development of countries, is followed by many stakeholders, especially investors. In the industrial sector, the production of value-added products needed by countries make this sector attractive among stakeholders. The industrial sector, like other sectors, is affected by economic developments and macroeconomic factors. However, these impacts change the development of countries, the performance of enterprises, and the earnings of investors. The deterioration and uncertainties in macroeconomic indicators (exchange rate, inflation, interest) of developing countries have an impact on many stakeholders. For example, in sectors with high import inputs, production costs will increase in parallel with the increase in the dollar price, which may lead to a decrease in demand as this leads to an increase in the sales price of the products. Again, with the increase in production costs, inflation will increase and deterioration in price stability may occur. Increases in interest rates will increase the financing costs of enterprises and may lead to a decrease in investments. Such negative developments will affect the costs, sales, debts, receivables, and profitability of the enterprises. Therefore, with these effects, there may be changes in the investment decisions of shareholders and investors.

When examining Turkey's economy, a deterioration in macroeconomic indicators after 2017 can be seen. In particular, the depreciation experienced in the Turkish Lira was 7\% in 2017, while this loss was around $40 \%$ in 2018. While the inflation rate was around $12 \%$ in 2017 , it rose to around $21 \%$ in 2018 . Similar increases were observed in interest rates, with interest rates rising from around $10 \%$ to around $24 \%$. The resulting negative developments that affected the industry impacted Turkey's leading sectors.

In this study, the economic deterioration experienced after 2017, was investigated to see whether the stock investors investing in industrial enterprises changed in how they made decisions. For this purpose, it was aimed

\section{Suggested Citation}

Avc1, T. (2020). Investigation of Financial Factors Affecting the Income of Share Certificates: An Example of Industrial Companies, Journal of Business Research-Turk, 12 (1), 146-156. 
to determine the financial factors affecting the stock returns of 147 enterprises in the Istanbul Stock Exchnge (BIST) industry sector and to reveal the differences in stock returns in 2017 and 2018. In the research and logistic regression analysis used, stock return ratio was a dependent variable and return on equity, market value / book value, price / earnings, receivables turnover ratio, inventory turnover ratio, asset turnover ratio, debt ratio, gross profit margin, and main operating profit margin ratios were used as independent variables.

\section{LITERATURE}

In this section, some of the studies carried out with different methods to determine the financial factors affecting the return on stocks are examined. In addition, the studies are examined in terms of data, methods, and results.

The literature, which uses financial ratios to estimate stock returns, began with Campbell and Shiller (1988), Fama and French (1988) mainly considered dividend and gain-price ratios.

Demir (2001) examined factors at the company level, which determine the stock price based on the financial sector. He determined that market value / book value, price / earnings ratio, profit per share, leverage ratio return on equity and net profit increase rate affect stock prices. In a study by Aktas (2009), the financial ratios related to stock returns were determined for the Istanbul Stock Exchange. He found that liquidity ratio, gross profit margin, and net profit margin ratios were positively significant. Cai and Zhang (2011) showed that the increase in leverage ratio decreased stock prices. In a study conducted for the Indonesian market, Fauzi and Wahyudi (2016) observed the effect of financial factors during stock market crashes on the performance of stocks with different characteristics. They determined that high debt ratio, low liquid assets, and low asset profitability factors adversely affected stocks. Senol, Koc, and Senol (2018) identified macroeconomic and internal factors that affect the prices of stocks. They concluded that asset profitability ratio, current ratio, and leverage ratio positively affected stock prices.

Ege and Bayraktaroglu (2009) investigated whether the stock returns of companies listed in the BIST 30 index could be explained by financial ratios. According to their results, price / earnings ratio, cash ratio, and turnover ratio of assets, were important in explaining stock returns. Karaca and Basc1 (2011) also examined factors affecting the performance of stocks in the BIST 30 index. According to them, net profit margin, main operating profit margin, asset turnover, and equity turnover ratios were found to be statistically significant. Aydemir, Ogel, and Demirtas (2012) examined the financial ratios, which were effective in determining stock prices by using a panel data method. According to the results of the analysis, profitability, liquidity, and leverage ratios had a positive effect on stock returns. Using panel regression analysis, Pech, Noguera, and White (2015) tested the relationship between financial ratios most favored by equity analysts and stock returns. According to the results, the most preferred financial ratio estimates of stock analysts had predictive power on stock returns after 1 year. Because of the research that examined the relationship between leverage and stock returns, Teng, Si \& Hachiya (2016) demonstrated a positive relationship between stock returns and leverage. Chong and Kim (2018) tested whether the volatility of the capital structure systematically affects stock returns. They showed a negative relationship between stock returns and capital structure volatility. McMillan (2019) estimated stock returns at a firm level. Statistically, he stated that the dividend-price ratio and the price-gain ratios had significant predictive joint activities.

In a study investigating the effect of financial leverage, Rayan (2008) found that the increase in financial leverage was negatively related to market value.

Table 1 shows the methods used to determine the factors affecting stock returns and some of the variables used in the analysis. 
T. Avc1 12/1 (2020) 146-156

Table 1. Methods and Variables Used in Determining Factors Affecting Returns on Stocks

\begin{tabular}{|c|c|c|c|}
\hline Authors & Methods & Independent variables & Dependent variables \\
\hline Demir (2001) & $\begin{array}{l}\text { Multiple regression } \\
\text { analysis }\end{array}$ & $\begin{array}{l}\text { Book to Market value } \\
\text { Earnings per share } \\
\text { Price/earnings } \\
\text { Return on equity } \\
\text { Dividend payment rate } \\
\text { Processing rate } \\
\text { Leverage ratio }\end{array}$ & Stock price \\
\hline Aktas (2009) & Logistic regression & $\begin{array}{l}\text { Return on equity } \\
\text { Gross profit margin } \\
\text { Debt ratio } \\
\text { Operating profit margin }\end{array}$ & Stock price \\
\hline $\begin{array}{l}\text { Senol, Koc \& Senol } \\
\text { (2018) }\end{array}$ & $\begin{array}{l}\text { Dynamic Panel } \\
\text { data analysis }\end{array}$ & $\begin{array}{l}\text { Asset profitability ratio } \\
\text { Inventory turnover } \\
\text { Current ratio } \\
\text { Leverage ratio }\end{array}$ & Stock price \\
\hline $\begin{array}{l}\text { Ege \& } \\
\text { Bayraktaroglu } \\
(2009)\end{array}$ & Logistic regression & $\begin{array}{l}\text { Liquidity ratios } \\
\text { Profitability ratios } \\
\text { Activity ratios } \\
\text { Stock performance ratios } \\
\text { Financial structure ratios } \\
\end{array}$ & Return on stock \\
\hline $\begin{array}{l}\text { Karaca \& Basçı } \\
(2011)\end{array}$ & Panel data analysis & $\begin{array}{l}\text { Return on equity } \\
\text { Receivable turnover } \\
\text { Inventory turnover } \\
\text { Debt ratio } \\
\text { Operating profit margin } \\
\end{array}$ & Return on stock \\
\hline $\begin{array}{l}\text { Aydemir, Ögel } \\
\text { \&Demirtas (2012) }\end{array}$ & Panel data analysis & $\begin{array}{l}\text { Return on equity } \\
\text { Operating profit margin } \\
\text { Debt ratio } \\
\text { Inventory turnover } \\
\text { Receivable turnover } \\
\text { Asset turnover }\end{array}$ & Return on stock \\
\hline $\begin{array}{l}\text { Pech, Noguera \& } \\
\text { White (2015) }\end{array}$ & Panel data analysis & $\begin{array}{l}\text { EBITDA margin } \\
\text { Return on equity } \\
\text { Dividend per share } \\
\text { Earnings per share } \\
\text { Growth in sales }\end{array}$ & Return on stock \\
\hline $\begin{array}{l}\text { Chong \& Kim } \\
\text { (2018) }\end{array}$ & Logistic regression & $\begin{array}{l}\text { Leverage ratio } \\
\text { Standard deviation of total debt } \\
\text { Trading volume / total stocks }\end{array}$ & Return on stock \\
\hline McMillan (2019) & Panel data analysis & $\begin{array}{l}\text { Dividend price ratio } \\
\text { Price-earnings ratio } \\
\text { Dividend ratio }\end{array}$ & Return on stock \\
\hline
\end{tabular}




\section{DATA AND RESEARCH METHODS}

In this analysis, companies were ranked according to their stock returns. The highest and the lowest-yielding companies were divided into two separate groups and the financial factors that affected the return on stocks were attempted to be determined. The logistic regression analysis method used in the study is given below.

Generally, logistic regression (LR) is well suited for testing and describing hypotheses about relationships one or more categorical or continuous predictor variables and between a categorical outcome variable (Peng, Lee \& Ingersoll, 2002, p. 4). Regression discovers empirical relationships between binary dependent and independent categorical and continuous variables. The predicted dependent variable in a logistic regression model is a function of the probability that a particular them will be in one of the categories. For example, the probability of change of a land use class based on a set of scores on predictor variables such as proximity to transport corridors, etc. (Arsanjani et al., 2012; Siddiqui et al., 2018).

The focus of logistic regression analysis is to establish a regression equation to predict which group of individuals is a member. The use of the logistics model dates back to about 1845. Logistic analysis, which is used mainly in the study of socio-economic subjects, has emerged in studies aimed at explaining the population increase in society with a mathematical expression (Gürcan, 1998; Cokluk, 2010, p.1359).

The main purpose of Logistic Regression Analysis is to investigate the causality relationship between independent and dependent variables. In other words, the aim is to construct a model with a descriptive variable using at least one variable. In the logistic regression method, there is no assumption that the dependent variable is continuous. It is used especially when the dependent variable has two or more qualitative values (Ulupinar, 2007, p. 39; Burmaoglu and Others, 2009). Logistic regression analysis may be preferred when the dependent variable is in binary form and it can be considered as an alternative approach for the purpose of classification (Bas and Cakmak, 2012, p. 68).

Generally, logistic regression model is formulated mathematically by relating the probability of some event, E, occurring, conditional on vector, $\mathrm{x}$, of explanatory variables, to vector $\mathrm{x}$, owing to the functional form of a logistic cdf. Thus (Press \& Wilson, 1978, p. 699).

$\mathrm{p}(\mathrm{x}) \equiv \operatorname{Pr}\{\mathrm{Elx}\}=1 /\left[1+\exp \left\{-\alpha-\beta^{\prime} \mathrm{x}\right\}\right]$,

where $(\alpha, \beta)$ are the unknown parameters that are estimated from the data. This model may be used for classifying an object into one of two populations by letting E denote the event that the object belongs to the first population, and letting $x$ denote a profile vector of attributes of the object to be classified.

The model function of logistic regression analysis is expressed as follows.

$$
E(y i)=\frac{\exp \left(\beta_{0}+\beta_{1} x_{1 j}+\beta_{2} x_{2}+\cdots \ldots \ldots \ldots+\beta_{j} x_{i j}\right.}{1+\exp \left(\beta_{0}+\beta_{1} x_{1 j}+\beta_{2} x_{2 j}+\cdots \ldots \ldots .+\beta_{j} x_{i j}\right.}
$$

This function is the logistics function. The result number of this function takes a value between 0 and 1 . This is because the result graphically has 0 and 1 asymptotes. If the result of this function is greater than 0.50 , the decision unit is classified as 1 and if it is smaller, it is classified as 0 (Aktas and Erkus, 2009; Akbulut and Rencber, 2015).

The basic logic of logistic regression is based on the likelihood that the decision unit is a member of a group or cluster. This probability is expressed as an odds number and formulated as follows (Akbulut and Rencber, 2015).

$$
\text { Odds } \frac{p(x)}{1-p(x)}
$$

In this study, it was aimed to determine the financial ratios that affected the stock returns of 147 industrial companies operating in the Istanbul Stock Exchnge. The financial ratios and market performance ratios of the companies for 2017- 2018 were used as data. The rate of return of the stocks of the companies was used as a dependent variable and financial ratios and stock market performance ratios of companies were used as independent variables. The financial ratios and calculation methods used are as follows. 
T. Avc1 12/1 (2020) 146-156

Table 2. Variables Used in the Analysis

\begin{tabular}{c|l|c|l}
\hline No. & \multicolumn{1}{|c|}{ Name of Variables } & Code of Variables & \multicolumn{1}{|c}{ Formula of Variables } \\
\hline 1 & Return Per Share Ratio & RPSR & $\begin{array}{l}\text { annual change in stock price (TL) / } \\
\text { stock price }\end{array}$ \\
\hline 2 & Return on Equity Ratio & ROE & net income / shareholder's equity \\
\hline 3 & Book to Market Value Ratio & (MTB) & market value/ book value \\
\hline 4 & Price-Earnings Ratio & P/E & $\begin{array}{l}\text { market value price per share/earnings } \\
\text { per share }\end{array}$ \\
\hline 5 & Receivables Turnover Ratio & RT & net credit sales/accounts receivable \\
\hline 6 & Stock Turnover Ratio & IT & cost of goods sold/ stock \\
\hline 7 & Asset Turnover Ratio & AT & net sales / total assets \\
\hline 8 & Debt Ratio & DR & total liabilities/total assets \\
\hline 9 & Gross Profit Margin Ratio & GRM & gross profit / net sales \\
\hline 10 & Operating Margin Ratio & OM & operating income / net sales \\
\hline
\end{tabular}

The financial ratios used in the research were obtained from the Istanbul Stock Exchnge website and the footnotes of the companies' balance sheets, income statements, and financial statements are in the Public Disclosure Platform.

\section{EMPIRICAL RESULTS}

In this analysis conducted to determine the financial factors affecting the returns of stocks of industrial enterprises, 147 industrial companies in the Istanbul Stock Exchnge were listed according to the stock return rates of 2017 and 2018. Then, 40 companies with high returns and 40 with low returns were divided into two groups. Not all 147 companies were taken into consideration in the stock return ranking and 67 companies were left between these two groups to ensure that the groups were not close to each other. In the research, the value of the companies in the group with high returns was given a value of 1 and the value of the companies in the lower group was given a value of 0 , and the data was made suitable for logistic regression analysis. While 1 and 0 values representing the stock return ratio were used as a dependent variable in the analysis; return on equity, market value / book value, price / earnings, receivables turnover, inventory turnover, asset turnover, gross profit margin, debt ratio, and operating profit margin ratios were used as independent variables.

As the result of the test was not normally distributed, it was decided to use logistic regression analysis. Secondly, the Spearman correlation test analysis was performed for the linear multiple connection problem, which is the basic assumption of logistic regression analysis. Thirdly, the Mann-Whitney $U$ test was used to test whether there was a significant difference between the financial ratios of 40 companies with high return on stocks and 40 companies with low return on stocks. Finally, LR analysis was conducted to determine the factors that affect the stock returns of investors.

For the 2017 and 2018 data, the normal distribution test was performed and the results are given in Table 3.

The normal distribution is a distribution with a mean of zero and a standard deviation of 1 . The kurtosis and skewness values of the distribution indicate whether the data set is normally distributed or not. In the normal distribution, the mode, median, and arithmetic mean are equal. The skewness value is divided by the skewness standard error value and is compared with the critical table values and the lower and upper limit of -1.96 - 1.96, which is the $5 \%$ significance level, and is considered to show normal distribution of data (Kalaycl, 2005, p. 6). 
T. Avc1 12/1 (2020) 146-156

Table 3. Normal Distribution Tests of Financial Ratios

\begin{tabular}{|c|c|c|c|c|c|c|c|c|c|c|c|c|c|}
\hline \multirow{3}{*}{\multicolumn{2}{|c|}{$\begin{array}{l}\text { Market Return Rate } \\
\text { (Capital Gain Rate) }\end{array}$}} & \multicolumn{6}{|c|}{2017} & \multicolumn{6}{|c|}{2018} \\
\hline & & \multicolumn{3}{|c|}{$\begin{array}{l}\text { Kolmogorov- } \\
\text { Smirnov }\end{array}$} & \multicolumn{3}{|c|}{ Shapiro-Wilk } & \multicolumn{3}{|c|}{$\begin{array}{l}\text { Kolmogorov- } \\
\text { Smirnov }\end{array}$} & \multicolumn{3}{|c|}{ Shapiro-Wilk } \\
\hline & & Sta. & $\mathrm{df}$ & Sig. & Sta. & $\mathrm{df}$ & Sig. & Sta. & $\mathrm{df}$ & Sig. & Sta. & $\mathrm{df}$ & Sig. \\
\hline \multirow{2}{*}{ ROE } & Low Return & .156 & 40 & .016 & .894 & 40 & .001 & .442 & 40 & .000 & .331 & 40 & .000 \\
\hline & High Return & .207 & 40 & .000 & .729 & 40 & .000 & .159 & 40 & .012 & .943 & 40 & .045 \\
\hline \multirow{2}{*}{ МTB } & Low Return & .321 & 40 & .000 & .615 & 40 & .000 & .466 & 40 & .000 & .328 & 40 & .000 \\
\hline & High Return & .277 & 40 & .000 & .635 & 40 & .000 & .252 & 40 & .000 & .793 & 40 & .000 \\
\hline \multirow{2}{*}{$\mathrm{P} / \mathrm{E}$} & Low Return & .247 & 40 & .000 & .573 & 40 & .000 & .409 & 40 & .000 & .355 & 40 & .000 \\
\hline & High Return & .407 & 40 & .000 & .492 & 40 & .000 & .372 & 40 & .000 & .558 & 40 & .000 \\
\hline \multirow{2}{*}{ RT } & Low Return & .202 & 40 & .000 & .889 & 40 & .001 & .518 & 40 & .000 & .154 & 40 & .000 \\
\hline & High Return & .470 & 40 & .000 & .177 & 40 & .000 & .477 & 40 & .000 & .208 & 40 & .000 \\
\hline \multirow{2}{*}{ IT } & Low Return & .239 & 40 & .000 & .523 & 40 & .000 & .164 & 40 & .008 & .782 & 40 & .000 \\
\hline & High Return & .198 & 40 & .000 & .772 & 40 & .000 & .195 & 40 & .001 & .797 & 40 & .000 \\
\hline \multirow{2}{*}{$\mathrm{AT}$} & Low Return & .085 & 40 & $.200^{*}$ & .985 & 40 & .871 & .090 & 40 & $.200^{*}$ & .972 & 40 & .427 \\
\hline & High Return & .151 & 40 & .022 & .916 & 40 & .006 & .133 & 40 & .072 & .879 & 40 & .000 \\
\hline \multirow{2}{*}{ DR } & Low Return & .090 & 40 & $.200^{*}$ & .961 & 40 & .183 & .114 & 40 & $.200^{*}$ & .955 & 40 & .114 \\
\hline & High Return & .107 & 40 & $.200^{*}$ & .954 & 40 & .105 & .145 & 40 & .034 & .927 & 40 & .013 \\
\hline \multirow{2}{*}{ GRM } & Low Return & .118 & 40 & .170 & .970 & 40 & .350 & .108 & 40 & $.200^{*}$ & .960 & 40 & .161 \\
\hline & High Return & .172 & 40 & .004 & .938 & 40 & .029 & .080 & 40 & $.200^{*}$ & .965 & 40 & .242 \\
\hline \multirow{2}{*}{$\mathrm{OM}$} & Low Return & .162 & 40 & .010 & .941 & 40 & .036 & .492 & 40 & .000 & .164 & 40 & .000 \\
\hline & High Return & .535 & 40 & .000 & .150 & 40 & .000 & .159 & 40 & .012 & .907 & 40 & .003 \\
\hline
\end{tabular}

The test value varies in the range $0-1$. Values close to 1 indicate that the variable has a normal distribution, and values close to zero indicate that the variable does not have a normal distribution (Aktas, 2018, p. 11).

In Table 3, when the data for 2017 and 2018 is analyzed, since the asset turnover rate, debt ratio, and gross profit margin ratios have a significance value greater than $5 \%$, these financial ratios are distributed normally and the other ratios are not normally distributed. In this context, instead of discriminant analysis requiring normal distribution of data, a logistic regression method, which does not require normal distribution, was used in the analysis.

Spearman correlation test is used to investigate the absence of linear connection problem, which is the assumption of the logistic regression method. The test results for 2017 and 2018 are presented in Table 4 and Table 5.

Spearman correlation is used in cases where the distribution of variables is far from normal. When the correlation between the two variables is $70 \%$ or more, a high relationship is mentioned (Sungur, 2018, p. 117). 
T. Avc1 12/1 (2020) 146-156

Table 4. Spearman's Rho Correlation Coefficient of Financial Ratios For 2017

\begin{tabular}{|c|c|c|c|c|c|c|c|c|c|}
\hline & 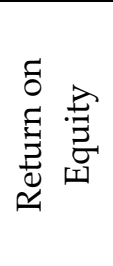 & 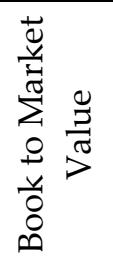 & 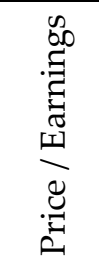 & 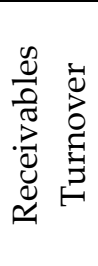 & 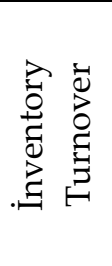 & 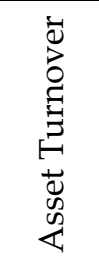 & 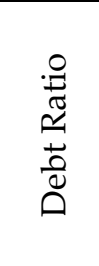 & 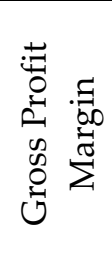 & 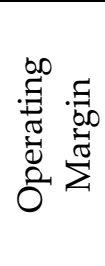 \\
\hline Return on Equity & 1.000 & & & & & & & & \\
\hline Book to Market Value & .325 & 1.000 & & & & & & & \\
\hline Price / Earnings & .017 & .349 & 1.000 & & & & & & \\
\hline Receivables Turnover & .220 & .018 & -.155 & 1.000 & & & & & \\
\hline İnventory Turnover & .073 & .199 & -.061 & -.028 & 1.000 & & & & \\
\hline Asset Turnover & .418 & .398 & -.021 & .225 & .366 & 1.000 & & & \\
\hline Debt Ratio & -.093 & .200 & .144 & -.034 & .185 & .207 & 1.000 & & \\
\hline Gross Profit Margin & .116 & .191 & -.010 & .041 & -.330 & -.313 & -.183 & 1.000 & \\
\hline Operating Margin & .515 & .059 & 183 & .218 & -.219 & -.174 & -.185 & .365 & 1.000 \\
\hline
\end{tabular}

Table 4 shows that the correlation coefficients of the independent variables used for 2017 are less than 0.70, which is the critical value for all variables. Therefore, it is understood that there is no linear connection problem in the data of this year.

Table 5. Spearman's Rho Correlation Coefficient of Financial Ratios For 2018

\begin{tabular}{|c|c|c|c|c|c|c|c|c|c|}
\hline & 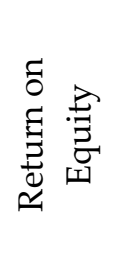 & 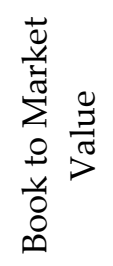 & 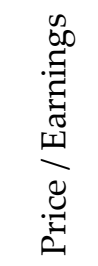 & 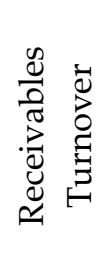 & 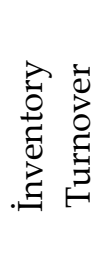 & 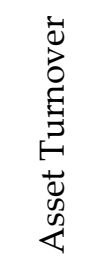 & 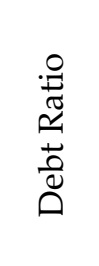 & 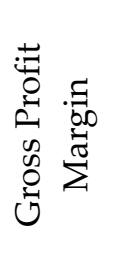 & 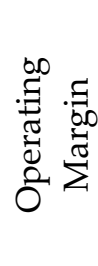 \\
\hline Return on Equity & 1.000 & & & & & & & & \\
\hline Book to Market Value & .019 & 1.000 & & & & & & & \\
\hline Price / Earnings & .504 & -.029 & 1.000 & & & & & & \\
\hline Receivables Turnover & .175 & .186 & .203 & 1.000 & & & & & \\
\hline İnventory Turnover & .026 & .224 & -.039 & -.006 & 1.000 & & & & \\
\hline Asset Turnover & .350 & .340 & .187 & .130 & .421 & 1.000 & & & \\
\hline Debt Ratio & -.267 & .272 & -.162 & -.150 & .119 & .270 & 1.000 & & \\
\hline Gross Profit Margin & .372 & -.050 & .250 & .078 & -.488 & -.091 & -.178 & 1.000 & \\
\hline Operating Margin & .643 & .029 & .356 & .102 & -.121 & .054 & -.206 & .650 & 1.000 \\
\hline
\end{tabular}

The correlation coefficients of the independent variables used for 2018 were also less than 0.70, which is the critical value for all variables in 2017. Therefore, it was understood that there is no linear connection problem in the data of this year.

The Mann-Whitney $U$ test is used to determine whether there is a significant difference between the financial ratios of the companies with high return on stocks and the companies with low return on stocks. The results of this test are given in Table 6 . 
T. Avc1 12/1 (2020) 146-156

Table 6. Mann- Whitney U Test

\begin{tabular}{|c|c|c|c|c|c|c|c|c|c|}
\hline & 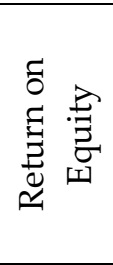 & 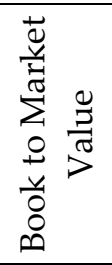 & 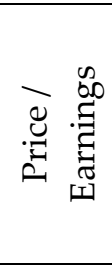 & 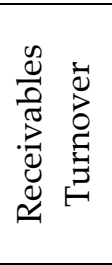 & 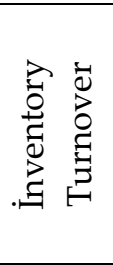 & 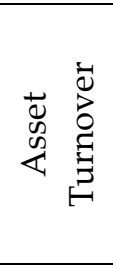 & 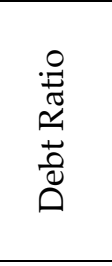 & 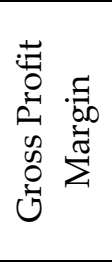 & 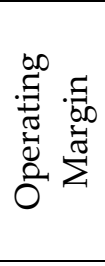 \\
\hline \multicolumn{10}{|l|}{2017} \\
\hline Mann-Whitney U & 430 & 713 & 565 & 697 & 652 & 676 & 745 & 669 & 688 \\
\hline Wilcoxon W & 1250 & 1533 & 1385 & 1517 & 1472 & 1496 & 1565 & 1489 & 1508 \\
\hline $\mathrm{Z}$ & -3.560 & -.837 & -2.261 & -.991 & -1.424 & -1.193 & -.529 & -1.261 & -1.078 \\
\hline Asymp. Sig. (2-tailed) & .000 & .403 & .024 & .322 & .154 & .233 & .597 & .207 & .281 \\
\hline \multicolumn{10}{|l|}{2018} \\
\hline Mann-Whitney U & 293 & 601 & 696 & 681 & 772 & 701 & 507 & 622 & 362 \\
\hline Wilcoxon W & 1113 & 1421 & 1516 & 1501 & 1592 & 1521 & 1327 & 1442 & 1182 \\
\hline $\mathrm{Z}$ & -4.879 & -1.915 & -1.001 & -1.145 & -.269 & -.953 & -2.819 & -1.713 & -4.215 \\
\hline Asymp. Sig. (2-tailed) & .000 & .056 & .317 & .252 & .788 & .341 & .005 & .087 & .000 \\
\hline
\end{tabular}

The Mann-Whitney $U$ test is a non-parametric hypothesis test and is used to test for differences between two independent groups. In this test, the median of the variables are compared, not the means (Aktas, 2018, p.11).

In Table 6, when first examined in 2017, the return on equity ratio was significant at a $99 \%$ significance level while the price / profit ratio was significant at a 95\% significance level. Next, when the 2018 test results were analyzed, it was seen that the return on equity, debt ratio, and main operating profit margin ratio were $99 \%$, market value / book value, and gross profit margin ratios were significant at $90 \%$. Because of the analysis, it was understood that these ratios, which are significant, could be used to differentiate between companies with high return on stocks and companies with low return on stocks.

The results of the LR analysis test conducted to determine the financial factors affecting the return on stocks of companies are given below. These test results were examined under 4 headings as the explanatory power of the model, the significance test of the model, the correct classification ratio of the model and the significance test of the parameters

The explanatory power of the model, which is the first of the presented tests related to logistic regression analysis, is given in Table 7.

Table 7. Model Explanation Power (Model Summary)

\begin{tabular}{c|c|c|c}
\hline & -2 Log likelihood & Cox \& Snell R Square & Nagelkerke R Square \\
\hline 2017 & 103.256 & .091 & .122 \\
\hline 2018 & 91.131 & .219 & .292 \\
\hline
\end{tabular}

The Nagelkerke R Square value in Table 7 shows how much of the dependent variable the independent variables explain. The explanatory power of the model is 0.292 in 2018 from 0.12 in 2017. Therefore, the return of stocks in 2018 is better explained by independent variables.

Table 8 shows the significance test of the model, which is the second of the tests presented for logistic regression analysis.

Table 8. Significance Test of Model (Hosmer and Lemeshow Test)

\begin{tabular}{c|c|c|c}
\hline & Chi-square & $\mathrm{df}$ & Sig. \\
\hline 2017 & 11.978 & 8 & .152 \\
\hline 2018 & 8.136 & 8 & .420 \\
\hline
\end{tabular}


The Significance (sig.) Value of this test is higher than 0.05, which means that the model is significant. According to the test results, this value was 0.152 in 2017 and 0.420 in 2018. The fact that the test values are higher than 0.05 indicates that the logistic regression model is significant.

The correct classification ratio of the model, which is the third of the presented tests for logistic regression analysis, is given in Table 9.

Table 9. Correct Classification Rate Model (Classification Table)

\begin{tabular}{l|c|c|c|l|l|c|c}
\hline \multicolumn{4}{|c|}{2017} & \multicolumn{4}{c}{2018} \\
\hline & $\begin{array}{c}\text { Low } \\
\text { Return }\end{array}$ & $\begin{array}{c}\text { High } \\
\text { Return }\end{array}$ & $\begin{array}{c}\text { Percentage } \\
\text { Correct }\end{array}$ & & $\begin{array}{c}\text { Low } \\
\text { Return }\end{array}$ & $\begin{array}{c}\text { High } \\
\text { Return }\end{array}$ & $\begin{array}{c}\text { Percentage } \\
\text { Correct }\end{array}$ \\
\hline Low Return & 32 & 8 & 80.0 & Low Return & 29 & 11 & 72.5 \\
\hline High Return & 12 & 28 & 70.0 & High Return & 16 & 24 & 60.0 \\
\hline $\begin{array}{l}\text { Overall } \\
\text { Percentage }\end{array}$ & & 75.0 & $\begin{array}{l}\text { Overall } \\
\text { Percentage }\end{array}$ & & & 66.3 \\
\hline
\end{tabular}

Table 9 shows the correct classification rate of companies with a high return on stocks and companies with a low return on stocks. While the total correct classification rate of the model was $75 \%$ in 2017 , it decreased to $66.3 \%$ in 2018.

Table 10 shows the significance test of the parameters of the model, which is the last of the tests presented for logistic regression analysis.

Table 10. Significance Test of Parameters (Variables in the Equation)

\begin{tabular}{l|c|c|c|c|c|c}
\hline \multicolumn{7}{c}{ Significance Test of Parameters in 2017} \\
\hline & B & S.E. & Wald & df & Sig. & $\operatorname{Exp(B)}$ \\
\hline Return on Equity & 3.237 & 1.484 & 4.760 & 1 & .029 & 25.456 \\
\hline Constant & -.445 & .307 & 2.099 & 1 & .147 & .641 \\
\hline \multicolumn{7}{l}{ Significance Test of Parameters in 2018} \\
\hline Debt Ratio & B & S.E. & Wald & df & Sig. & $\operatorname{Exp(B)}$ \\
\hline Operating Margin & -2.807 & 1.148 & 5.982 & 1 & .014 & .060 \\
\hline Constant & 4.770 & 1.900 & 6.306 & 1 & .012 & 117.953 \\
\hline
\end{tabular}

Table 10 shows the financial ratios and coefficients that are significant in the model. First, when the results of the analysis were evaluated in 2017, the return on equity was found to be significant. This ratio is significant at a $95 \%$ confidence level and has a positive effect of 3.237 on the effect of stock returns. Secondly, when the findings of 2018 are evaluated, it is seen that the debt ratio and the operating profit margin ratio are significant. Both rates were significant at a $95 \%$ confidence level. While the debt ratio had a negative effect of 2.807 on the effect of stock returns, the operating profit margin had a positive effect of 4.770 .

\section{CONCLUSION}

In this study, it was aimed to determine the financial factors that affect the return of stocks of companies by using 2017 and 2018 data of 147 industrial companies traded on the Istanbul Stock Exchnge. As data in the research, return on stocks of companies was used as a dependent variable; return on equity, market value / book value, price / earnings, receivables turnover, inventory turnover, asset turnover, debt ratio, gross profit margin, and operating profit margin ratios were used as independent variables. In the research, where annual data was used, according to the stock returns, 147 companies were divided into two groups as 40 high-return companies and 40 
low-return companies. In the analysis, normal distribution test, correlation test, Mann-Whitney U test and Logistic regression tests were used.

Firstly, when the logistic regression analysis findings of 2017 were analyzed, it was seen that the return on equity was significant at a $95 \%$ confidence level. This ratio affects stock return positively by 3.237 . This means that if the return on equity increases by $1 \%$, stock returns will increase by approximately $3 \%$, and if $1 \%$ decreases, stock returns will decrease by $3 \%$.

Secondly, when the 2018 findings were evaluated, it was seen that the debt ratio and operating profit margin ratio was significant at a $95 \%$ confidence level. According to the coefficients of the variables, while the debt ratio on stock returns had a negative impact of 2.807 , the operating profit margin had a positive impact of 4.770 . This means that when the debt ratio increases by $1 \%$, stock returns will decrease by approximately $2.8 \%$, and if there is a $1 \%$ decrease, stock returns will increase by $2.8 \%$. When the operating profit margin increases by $1 \%$, stock returns will increase by approximately $4.7 \%$ and when there is a $1 \%$ decrease, stock returns will decrease by $4.7 \%$.

Looking at both year's results, it can be seen that the financial factors on stock returns changed. Based on these results, it can be said that in 2017, investors made investment decisions by looking at the equity profitability ratios of industrial companies in order to obtain returns from stocks. With the impact of the macro-economic deterioration, it can be assumed that in 2018, the investors decided to invest according to the debt ratio and operating profit margins of the industrial companies in order to obtain returns from the stocks.

\section{REFERENCES}

Akbulut, R., \& Rencber, Ö. F. (2015). Evaluation of Efficiencies Based on Financial Performance with Data Envelopment and Logistic Regression Analysis in the Cement Businesses. Journal of Alanya Faculty of Business/ 7(3).

Aktas, M. (2009). A Research on Financial Ratios Related to Stock Returns in the Istanbul Stock Exchange. Istanbul Business Research, 37(2), 137-150.

Aktas, M. (2018). Financial Ratios Affecting the Profitability of Manufacturing Companies Operating in Bourse Istanbul. Ramazan Akbulut \& Omer Faruk Rencber (Ed.), Analysis on Companies and Financial Institutions Within (1-21). Istanbul, Kriter Publisher.

Arsanjani, J. J., Helbich, M., Kainz, W., \& Boloorani, A. D. (2013). Integration of Logistic Regression, Markov Chain and Cellular Automata Models to Simulate Urban Expansion. International Journal of Applied Earth Observation and Geoinformation, 21, 265-275.

Bas, M., \& Cakmak, Z. (2012). Determining the Financial Failure in Enterprises Using Grey Relational Analysis and Logistic Regression Analysis \& an Application. Anadolu University Journal of Social Sciences

Burmaoglu, S., Oktay, E., \&, Ozen (2009). Comparing Classification Success of Discriminant Analysis and Logistic Regression Analysis Using United Nations Developing Programme's Human Development Index. The Journal of Defense Sciences, 8(2), 23-49.

Cai, J., and Zhang, Z. (2011), "Leverage Change, Debt Overhang, and Stock Prices. Journal of Corporate Finance", 17(3), s. 391-402

Campbell, J. Y., \& Shiller, R. J. (1988). The Dividend-Price Ratio and Expectations of Future Dividends and Discount Factors. The Review of Financial Studies, 1(3), 195-228.

Chong, B. U., \& Kim, H. (2018). Capital Structure Volatility, Financial Vulnerability, and Stock Returns: Evidence from Korean Firms. Finance Research Letters.

Cokluk, Ö. (2010). Logistic Regression Analysis: Concept and Application. Educational Sciences in Theory and Practice, 10(3), 1357-1407. 
Demir, Y. (2001). Business Level Factors Affecting Stock Price and an Application on Financial Sector. Suleyman Demirel University, The Journal of Faculty of Economics and Administrative Sciences, 6(2).

Ege, İ., \& Bayrakdaroglu, A. (2012). An Analysis of the Performance of Companies Stock Yields Using the Logistic Regression Method. ZKU Journal of Social Sciences, Volume 5, Number 10, 2009, pp. 139-158

Fama, E. F., \& French, K. R. (1988). Dividend Yields and Expected Stock Returns. Journal of Financial Economics, 22(1), 3-25.

Fauzi, R., \& Wahyudi, I. (2016). The Effect of Firm and Stock Characteristics on Stock Returns: Stock Market Crash Analysis. The Journal of Finance and Data Science, 2(2), 112-124.

Gürcan, M. (1998). Logistic Regression Analysis and an Application. Unpublished Master's Thesis, Ondokuz Mayis University, Institute of Science and Technology, Samsun

Kalaycı, Ş. (2005), SPSS Applied Multivariate Statistical Techniques, 1. Edition, BRC Matbaacılık Asil Yayın Dağıtım Ltd. Şti.

Karaca, S. S., \& Basci, E. S. (2011). The Ratios Affecting Stock Performance and Panel Data Analysis in BIST 30 Index During 2001-2009. Suleyman Demirel University the Journal of Faculty of Economics and Administrative Sciences, 16(3), 337-347.

McMillan, D. G. (2019). Predicting Firm Level Stock Returns: Implications for Asset Pricing and Economic Links. The British Accounting Review.

Pech, C. O. T., Noguera, M., \& White, S. (2015). Financial Ratios Used by Equity Analysts in Mexico and Stock Returns. Contaduríay Administración, 60(3), 578-592.

Peng, C. Y. J., Lee, K. L., \& Ingersoll, G. M. (2002). An Introduction to Logistic Regression Analysis and Reporting. The Journal of Educational Research, 96(1), 3-14.

Press, S. J., \& Wilson, S. (1978). Choosing Between Logistic Regression and Discriminant Analysis. Journal of the American Statistical Association, 73(364), 699-705.

Rayan, K. (2008), “Financial Leverage and Firm Value”, Master Thesis, University of Pretoria

Siddiqui, A., Siddiqui, A., Maithani, S., Jha, A. K., Kumar, P., \& Srivastav, S. K. (2018). Urban Growth Dynamics of an Indian Metropolitan Using CA Markov and Logistic Regression. The Egyptian Journal of Remote Sensing and Space Science, 21(3), 229-236.

Sungur (2018). Correlation Analysis. Kalaycı Esref (Ed.), SPSS Applied Multivariate Statistical Techniques Within (115-127), Dynamic Academy, 8th Edition

Senol, Z., Koc, S., \& Senol, S. (2018). An Analysis of Dynamic Panel Data Analysis of the Factors Affecting the Prices of Stocks. Gümüşhane University Electronic Journal of the Institute of Social Sciences, 9(25).

Teng, M., Si, J., \& Hachiya, T. (2016). Banking Relationship, Relative Leverage and Stock Returns in Japan. PacificBasin Finance Journal, 40, 86-101.

Ulupinar, S. D. (2007); 2001 Research on Profitability of Turkish Commercial Banks Before, During and After 2001 Economical Crisis by Logistic Regression Analysis Method, Department of Statistics, Master Thesis, Marmara University, Istanbul 